Maina, M. \& Garcia, I. (2016). Articulating personal pedagogies through learning ecologies. In B. Gros, Kinshuk, \& M. Maina (Eds.), The Future of Ubiquitous Learning: Learning Designs for Emerging Pedagogies (pp. 73-94). Lecture Notes in Educational Technology. Berlin Heidelberg: Springer. doi: 10.1007/978-3-66247724-3

\title{
ARTICULATING PERSONAL PEDAgOGIES THROUGH LEARNING ECOLOGIES
}

\author{
MARCELO F. MAINA \& IOLANDA GARCÍA GONZÁLEZ
}

\begin{abstract}
The digital revolution enabled by social and ubiquitous technologies is constantly transforming macro and micro levels of society including industry, organizations and government as well as ways in which we communicate, we work, and we carry on our daily lives. Education is therefore also being challenged to respond to evolving societal demands by supporting the development of competent and engaged citizens. In this context, individuals' capability to get involved and exploit the affordances of networked environments for learning and development may condition their opportunities to cope with societal and labor demands. In this chapter, the metaphor of learning ecologies is proposed to provide a framework from which to analyze interactions between individuals and their environment, and the way their experiences across different contexts throughout life promote and shape learning processes. Learning ecologies allow us to explore frontier pedagogies connecting formal, non-formal and informal educational contexts, acting as personal strategies that may orchestrate life-long, life-wide and life-deep learning. We start by defining and framing learning ecologies, providing the theoretical roots and reviewing some recent studies in the field. Next, we propose constructs and models but also strategies and tools that may be of help to enhance and support personal ecologies for learning. Finally, the concept of personal pedagogies is proposed to refer to a set of autonomy and agency skills and attitudes that can be dynamically integrated by individuals to support an ecology for self-development and personal learning. We articulate from this perspective several trends in the area of self-directed learning located in the technological and pedagogical intersection: MOOCs, current awareness, e-portfolios and social networks.
\end{abstract}


Key words: learning ecologies, personal pedagogies, networked learning, social networks, personal learning environments, life-long learning

\section{INTRODUCTION}

Ubiquitous technology is rapidly transforming the ways in which we communicate, work and carry on our daily lives. The digital revolution is impacting on all kinds of industry, organizations and government institutions. Education in particular is being challenged to respond to evolving societal demands by not only adapting its own curriculum and modes of education delivery, but more importantly by offering quality education that supports the development of competent people and engaged citizens.

In this chapter, rather than focusing on an institutional or teacher point of view, we situate ourselves within the perspective of the individual coping with constant challenges in every area of their life and requiring different ways of engaging with learning and development.

Through this privileged view we explore frontier pedagogies connecting formal, non-formal and informal educational contexts as a personal strategy that orchestrates life-long (overtime competence development and knowledge acquisition), life-wide (across social settings) and life-deep (beliefs and values) learning (Heimlich \& Horr, 2010).

A humanistic approach to learning (Kanuka, 2008) emphasizes a balance between individual and social commitment characterized by "freedom and autonomy, trust, active cooperation and participation, and self-directed learning" (p. 106). Networked technologies and social media are integral parts of this ecology where the person pivots their learning based on "intrinsic motivation, self-concept, self-perception, self-evaluation, and discovery" (p. 107).

Brown (2000) was a pioneer in using the ecology metaphor applied to learning: "ecology is basically an open, complex, adaptive system comprising elements that are dynamic and interdependent. One of the things that makes an ecology so powerful and adaptive to new environments is its diversity" (p.19). The ecological metaphor provides a productive framework for observing and analyzing interactions between people and their environment, their experiences across different contexts throughout life and the way these activities promote and shape learning processes. Lifelong 
through learning ecologies. In B. Gros, Kinshuk, \& M. Maina (Eds.),

The Future of Ubiquitous Learning: Learning Designs for Emerging

Pedagogies (pp. 73-94). Lecture Notes in Educational Techno.

Articulating personal pedagogies through learning ecologies

learners, through their participation in diverse communities, weave their own learning ecologies and in doing so they construct and organize personalized and unique connections and interactions with objects and individuals.

From this perspective, the capacity to create and sustain a learning ecology increases personal opportunities for learning, development and achievement (Jackson, 2013). At the same time, the extent to which people achieve certain learning goals and personal development depends upon structural factors like the actual availability of resources and the internal learning stimuli (Biesta \& Tedder, 2007).

In the era of social and ubiquitous technologies, hybrid, amplified and enriched contexts provide individuals with multiple ways of getting involved and exploiting opportunities for learning and development. In this chapter we argue that learning ecologies can sustain the articulation of different types of personal pedagogies that support self-directed learning itineraries and trajectories throughout life.

\section{DEFINING LEARNING ECOLOGIES: THEORETICAL FOUNDATIONS AND FRAMEWORKS}

\subsection{Approaching learning ecologies}

The ecological perspective considers people as a part of a living and dynamic system with physical, social and also virtual dimensions, located in a particular cultural and historic time and spatial frame.

Learning ecologies have been studied from diverse perspectives, most of them sharing a socio-cultural view of learning, such as communities of practice (Wenger, 1998; Wenger, McDermott \& Snyder, 2002), actor network theory (Law, 1992) and activity theory (Engestrom, 2000), but they have also been associated with alternative frameworks like connectivism (Siemens, 2005; Downes, 2012), or Cormier's rhizomatic approach (2008). The basic assumption in all cases is that learning is socially and culturally constructed and that technology can be considered a tool that mediates our interpretation of what we experience within the world. In this sense, all kinds of connections and relationships, especially interpersonal ones, can be considered as fundamental resources for personal growth and development. 
Chapter Maina, M. \& Garcia, I. (2016). Articulating personal pedagogies through learning ecologies. In B. Gros, Kinshuk, \& M. Maina (Eds.), The Future of Ubiquitous Learning: Learning Designs for Emerging Pedagogies (pp. 73-94). Lecture Notes in Educational

Techno

Nardi and O'Day (1999) first discussed the concept of information ecologies as the flows of information that circulate in organizations or in specific local environments and the system of people, practices and technologies that participate in or contribute to this flow. Lemke (2000) advanced the notion of learning ecologies composed of temporal and spatial dimensions connecting past and present moments, and linking life actions to significant experiences. From this perspective, physical and virtual, formal and informal spaces can be considered as potential environments for learning.

Siemens (2007, p.63) emphasizes this wide spatial dimension of learning ecologies as "the space in which learning occurs", to the extent that a particular type of learning taking place in a specific space can be considered as a property of that space (Thomas, 2010). Siemens also highlights the relational and informal nature of learning ecologies as "an environment that fosters and supports the creation of communities" (2003, p. 17). This author describes a learning ecology as: informal, not structured, tool-rich, consistent and evolving along time, highly social, decentralized, and connected and experiential. His idea of a learning ecology is therefore very close to the concepts of community and network. Communities make up a learning ecology by acting as nodes in a personal learning network: "if ecologies are the spaces of learning, then networks are the structures of learning". Connectivism would therefore be the theoretical umbrella to understand networks as an organizing scheme of knowledge, and learning would be considered an activity that is mainly based on the creation and navigation of networks (Siemens, 2008).

As Esposito, Sangrà and Maina (2015) explain, the ecology metaphor also "sheds light on the entangled facets of socio-cultural activities and educational contexts (p. 331). Formal educational settings and experiences are also constituents of learning ecologies: institutions, teachers and the foundational pedagogical model play an important role in structuring their components. Haythornthwaite and Andrews (2011) explore the interpretation of learning ecology within the e-learning domain. From their perspective, the metaphor is useful to understand e-learning as a complex and systemic phenomenon, where no processes can be predefined. Goodyear (1998) introduces the notion of "ergonomics of learning environments" to emphasize the importance of considering in e-learning design what the learner work entails in relation with his or her own environment. 
through learning ecologies. In B. Gros, Kinshuk, \& M. Maina (Eds.),

The Future of Ubiquitous Learning: Learning Designs for Emerging

Pedagogies (pp. 73-94). Lecture Notes in Educational Techno.

Articulating personal pedagogies through learning ecologies

The informal learning dimension completes the picture of a personal leaning ecology. Kemmis, Wilkinson, Hardy and Edwards-Groves (2009) refer to this as ecologies of practice to name a set of particular practices that have an interdependent relationship and sustain and support each other. Practices are understood as "an organized nexus of actions that hold participants together and orchestrate them in relation to one another" (2009, p.17). A series of principles define the type of relationship established among practices: networks, nested, systems, interdependent relationships, cycles, development and dynamic balance.

A few number of learning ecology frameworks have been proposed in the literature so far. Richardson (2002) developed a holistic theoretical model for analyzing and interpreting a learning ecology. The model applies mainly to formal education. It is composed of two intersecting axes. The horizontal axis moves from a focus on the learning content to a focus on the learning activity. The vertical axis shows who drives the learning process: the learner (top), or a "guide" -human or machine-based agent- (bottom). The crossing of the axes creates four quadrants. While the upper quadrants target independent study (left side) and active learning experiences like problem or project based learning (right side), the lower quadrants target learning experiences directed by an external guide, i.e. a lecture, or a guided discussion (left side), or guided practices and exercises (right side).

Jackson (2013) proposes an adaptation of this framework to include informal learning experiences. The vertical axis represents learning through autonomous and independent activities (top), and learning that is facilitated through significant people along individuals' life experiences, such as family, friends, managers, etc. (bottom). The horizontal axis corresponds to the contexts in which learning takes place, including formal learning environments (left) and informally structured environments in which learning is an eventual result of engaging in diverse experiences or tasks (right). The crossing of the axes gives place to four different learning ecology scenarios, whether learning is partly or completely determined by an external provider or by the learner himself: a) traditional formal educational learning ecology; b) enquiry, problem and project-based learning ecologies; c) self-directed but supported learning ecologies and d) independent selfdirected learning ecologies. In his model, Jackson introduces new elements, such as the use of open educational resources and open educational practices in the learning experiences determined by the learner taking place in informal learning contexts. 
Chapter Maina, M. \& Garcia, I. (2016). Articulating personal pedagogies through learning ecologies. In B. Gros, Kinshuk, \& M. Maina (Eds.), The Future of Ubiquitous Learning: Learning Designs for Emerging Pedagogies (pp. 73-94). Lecture Notes in Educational

Techno

\subsection{Networked learning and learning ecologies}

The new forms of mobile, social and networked technologies and digital resources have amplified opportunities for flexible and self-organized learning practices. The role of technology is therefore a key element in shaping learning ecologies that blur the boundaries between formal and informal learning. As Frielick (2004) states "here we enter the zone of confluence between the emergent ecological idea and networked information technologies". The metaphor of a learning ecology is also used by Brown (2000) to describe how the vast amounts of available and interconnected resources on the Net provide an environment that fosters learning. This mainly refers to what Weller (2011) calls a "pedagogy of abundance" where collections of distributed resources are accessible, thus enabling emergent forms of learning, and where learner agency and social interaction merge. The Net becomes the playground where opportunities for learning are supported, enacted and fostered. The network is a moldable and empowering environment where individuals may gradually develop learner-generated contexts (Luckin et al., 2010). These contexts are a set of Net configurations for learning of variable stability, yet flexible enough to support different learning purposes.

Networked learning, as a "genre of technologically-mediated learning" where "social media and web technologies are used to promote connections between learner, human resources, content resources and learning communities and keep continually dealing with ever-increasing amount of digital information" (Saadatmand \& Kumpulainen, 2012, p.268), is another concept akin to the notion of learning ecology. From this perspective, learning happens in a multi-directional, multi-modal and dynamic way facilitated by web 2.0 socio-technical infrastructures bounded by the learner's choice of spaces, tools, contents, social interactions, etc. which configures what has been called a Personal Learning Environment (PLE). PLEs are in fact an approach to learning through social and participatory media applications based on learner configuration and self-management as opposed to Learning Management Systems (LMS), which are spaces controlled by the teacher or the institution (Attwell, 2007; Downes, 2007). The concept of PLEs closely corresponds to that of a learning ecology, in which learners organize their set of resources, applications, services as well 
through learning ecologies. In B. Gros, Kinshuk, \& M. Maina (Eds.),

The Future of Ubiquitous Learning: Learning Designs for Emerging

Pedagogies (pp. 73-94). Lecture Notes in Educational Techno.

Articulating personal pedagogies through learning ecologies

as personal contacts that may be useful to learn based on their own interests and preferences. To some extent, PLEs could be considered as a resource that every learner could use to connect, organize and take advantage of the different social communities and networks that integrate their learning ecology. The PLE has sometimes tended to focus on the technological perspective based on the availability of tools that are chosen, configured and managed by learners themselves. Several authors have preferred to use alternative concepts such as Personalized Learning Ecologies (Rongbutsri, Ryberg \& Zander, 2012) or Personal Learning Network to emphasize the technical, personal, social and intentional dimensions of learning.

\subsection{Driving personal ecologies for learning}

The purpose of this chapter is to focus on the individual learner perspective of learning ecologies. Barron's learning ecologies framework (2006) explains how learning takes place across settings, identifying the possible synergies and barriers between them, including the role of technology in making boundaries more permeable and allowing for new levels of agency in learning. The individual is "the organizing central node in the system" (Barron, 2004, p.6), and therefore responsible for its particular configuration: "each context comprises a unique configuration of purposes, activities, material resources, relationships and the interactions and mediated learning that emerge from them" (Barron, 2006, p.195). Unlike other authors, she focuses on how people contribute to their own development through selfinitiated learning activities and by appropriating and adapting resources within and across contexts. She builds her learning ecology framework on three assumptions (Barron, 2006, pp. 200-201) within any life space: 1) a variety of ideational resources can spark and sustain interest in learning; 2) people not only choose but also develop and create learning opportunities for themselves once they are interested, assuming they have time, freedom and resources to learn; and 3) interest-driven learning activities are boundarycrossing and self-sustaining.

The idea of intentional activities and processes is also brought up by Barab and Roth (2006) who explain that perceptual and cognitive affordances collectively form a network for particular goal sets. From this perspective, an ecology is intentionally created by individuals or groups in order to achieve their goals. There is an inherent purpose that gives meaning 
to our interactions with the world, although the process of shaping our learning ecology is "part planned and deliberate, and part intuitive, accidental and opportunistic" (Jackson, 2013, p.7).

This individual view of learning ecologies considers the learner as the main actor in the network, responsible for maintaining social relationships and creating meanings throughout physical and virtual contexts (Haythornthwaite and Andrews, 2011). In a more or less conscious and intentional way, the person is in command of their own learning context, by connecting people, objects and environments that support their learning. This approach requires self-directed skills that allow new learning models supporting personal learning and development to be envisioned and put into practice.

Williams, Karousou and Mackness (2011, p.43) propose the term "emergent learning" to designate this type of self-organized, open and collaborative knowledge generation that is mainly distributed by learners themselves within digital communities and networks. Emergent learning is unpredictable but retrospectively coherent since it takes place in complexadaptive domains as opposed to predictable ones. This "emergent behavior" is sustained by the new generation of technology-mediated dissemination and communication, where interest is mainly directed towards the interaction and collaboration at scale through social media and networking. It also requires adequate monitoring and a speedy response. In order to avoid any negative effects, the authors suggest that emergent learning should ideally be integrated into a wide and inclusive learning ecology that also includes other types of prescriptive learning.

\section{STUDIES OF ECOLOGIES FOR LEARNING}

Recent studies focus on better understanding the nature of learning processes, activities and how knowledge is created in open, social and networked learning environments. The metaphor of learning ecologies is often evoked in a more or less direct way as a framework to analyze and to explain personal learning and development processes. For example, Saadatmand and Kumpulainen (2012) explore open learning practices mediated by networked technologies and web 2.0 applications. Their study analyzes the type of learning activities and experiences that result from participating in these environments, the perceived values that participants 
through learning ecologies. In B. Gros, Kinshuk, \& M. Maina (Eds.),

The Future of Ubiquitous Learning: Learning Designs for Emerging

Pedagogies (pp. 73-94). Lecture Notes in Educational Techno.

Articulating personal pedagogies through learning ecologies

assign to them and how they conceptualize personal learning. They apply virtual ethnography as a research design in the context of a MOOC. The main results refer to the type and ways in which participants choose and customize the available tools (Facebook, blogs, Twitter, YouTube and RSS) depending on their goals and needs. The opportunity to connect across different platforms is perceived by participants as facilitating access to resources and experts. The possibility of being involved in simultaneous activities and using many different tools is motivating and enhances their learning autonomy, but it can otherwise be overwhelming, time consuming and too disruptive, especially if learners are not "armed" with the necessary digital and informational competencies to manage time, tools and information. Openness might also be experienced as a not fully comfortable context, where some participants may feel too exposed to others and pulled away from their own focus of interest. The research concludes that learning resulting from open and networked environments is self-organized, emergent and disruptive. In this sense, many learners may experience tension between the liberating feeling of greater agency and autonomy, and the confusion or frustration encountered when they are not capable of managing their learning. In a different study, Bonzo (2012) analyzed the perceptions and experiences of learning technology professionals regarding what he calls their Social Media Networked Learning Ecology (SMNE), as they engage in professional development and learning experiences. Using a phenomenographic research approach he analyzed the individuals' different levels of awareness and their conceptions of the connections and the relationships they established in their respective learning ecologies. He also explored how useful they perceived these relationships and connections to be in supporting their professional development and learning.

From a slightly different perspective, Luckin $(2008,2010)$ has carried out a number of studies to develop and give empirical ground to the Ecology of Resources Framework. In this case, the learning ecology fundamentally takes into account the resources with which an individual may interact. These resources, namely knowledge and skills, tools and people and the environment itself, act as potential forms of assistance that can facilitate learning. 


\section{ENHANCING AND SUPPORTING PERSONAL ECOLOGIES FOR LEARNING}

If we consider the Net as a ground for learning, it might be of interest to analyze the specific properties that contribute to supporting and enhancing a learning ecology. Looi (2001) provides an insightful analysis pointing out that the relationships that develop on the Net -while people participate and shape their own ecologies-, provide an identity and a social value for tools, spaces and content. In this way, people also contribute to the evolution of the Net by becoming active participants and knowledge producers. The increasing availability and easiness of authoring and delivery mechanisms has greatly facilitated the creation and maintenance of a learning ecology by any individual. Looi also draws attention to the need to "move towards the creation of learning content objects that can be reused, searched and modified independently on their delivery mechanism" (2001, p.17). This necessarily demands the development of applications and systems that are truly interoperable. In this respect many authors have advocated a shift from the delivery of high-quality content towards open informal content that can be manipulated, recreated and repurposed (Thomas, 2010). Another strategic development Looi mentions for enhancing ecological systems' individual support is to provide them with mechanisms to track others' actions, capturing the interaction history or mapping and trailing itineraries that may help others to suggest where to find good information, interesting connections, or simply how to solve technical problems. The affordances provided by social media for (audio) visual and verbal rich representations that can also be annotated by others enrich the possibilities for providing multiple perspectives of a phenomenon, contextualizing it and focusing through discourse on particular aspects. Finally, the use of tools supporting participatory storytelling combined with creative content involving entertainment, education and aesthetics can also contribute to making a learning ecology more engaging.

From an approach based on supporting digital devices, Tabuenca, Ternier and Specht (2012) analyzed adults' learning practices in order to recognize patterns of lifelong learners. The aim of the study was to shed light on new ways to support lifelong learners with technology and specifically with devices that allow for ubiquitous learning across different physical spaces and learning tasks. They defined patterns based on aspects such as the day of the week, duration, location activity, type of device chosen by the learners 
through learning ecologies. In B. Gros, Kinshuk, \& M. Maina (Eds.),

The Future of Ubiquitous Learning: Learning Designs for Emerging

Pedagogies (pp. 73-94). Lecture Notes in Educational Techno.

Articulating personal pedagogies through learning ecologies

whenever they take the initiative to learn. Some of the findings revealed that ownership of a smartphone may enhance not only opportunities but also motivation to learn during the day. Furthermore, the study showed certain associations between the type of learning activity performed and the location and situation where it mainly took place. Smart objects that can be found in both formal and informal learning environments through a variety of applications are generally perceived in an isolated manner, which means they are rarely interconnected or integrated in a "personalized seamless learning environment". Their educational purpose or possibilities are in most of the cases not obvious. Thus, the authors conclude that there is a need to orchestrate technologies that augment learning opportunities in physical spaces, so that they can be better integrated and managed in a personal learning flow.

Considering the educational perspective, we may identify some trends emerging from open, networked and social learning that necessarily intersect with many of the aspects we have put forward in the technological domain.

The idea of "limitless dimensions of learning" (Siemens, 2008) leads us to consider and recognize the value of the broad-spectrum of learning situations and modes of personal and collective development that may arise inside but also outside formal education institutions.

The rise of social computing based on social production and mass collaboration has caused a shift towards cultures of participation, where individuals have the opportunities and the means to contribute actively in content creation but also in addressing issues and tackling problems that are meaningful to them (Fischer, 2011). What has been called a "participative" or "participatory web" with "user-created content" as one of its main characteristics raises the need for a "participatory pedagogy". From this perspective, pedagogical models would not be fully defined in advance but in the process of interacting with learners, thus including multiple perspectives and active creation on the part of learners (Siemens, 2008).

The diversity of learners with different and evolving needs poorly addressed by formal education calls for personalized and flexible learning. This reality, together with the wide variety of possible learning situations, should result in the recognition of multiple itineraries and methodological approaches to support learners, some of them based on structured pathways and others more flexible and based on individual or collective self-directed exploration of subject matters, real-life problems or projects. 
Finally, enlarging the concept of accrediting learning and knowledge also seems to be a necessary step in this context. Siemens (2008) advocates a broad and holistic accreditation approach relying on multiple learning opportunities and trajectories throughout life, both in formal and informal contexts.

\section{TOWARDS THE ARTICULATION OF PERSONAL PEDAGOGIES THROUGH LEARNING ECOLOGIES.}

\subsection{The self and the pedagogies}

Managing one's own personal development is an ongoing process based on self-awareness, reflection, goal-setting, and defining a course of action. A "personal development plan" (Nixon, 2013) calls for conscious and intentional planning directed towards envisioned educational, professional or life accomplishments and based on thoughtful decisions regarding learning and development connecting educational contexts, workplace, and everyday life. Moore's theory of transactional distance highlights that "learner autonomy involves the learner's ability to create a learning plan, find resources that support study, and self-evaluate" (Andrade \& Bunker, 2009, p.48).

Biesta and Tedder (2007) propose an ecological understanding for the concept of agency that may also be useful to frame the idea of personal pedagogies. In their perspective, agency is defined as an achievement, enabled by individuals' engagement with temporal-relational contexts-foraction. So it has mainly to do with people's capacity to shape their responses to the situations they find in their lives, as the interplay of individual efforts, available resources and contextual and structural factors in particular situations. According to these authors, learning to recognize one's "agentic orientations and constellations" (p. 137) and how to reframe them can facilitate one's responsiveness, so it is important for individuals to distance themselves from their actions in order to be able to explore and evaluate them. 
Different authors (Holec, 1979/1981; Scharle \& Szabó, 2000; Smith, 2003; Wenden, 1998) characterize autonomy as persistent involvement and deliberate choice. The main autonomous traits point to:

- Setting individual goals.

- Selecting appropriate and accurate materials according to their own learning styles.

- Selecting activities according to their learning objectives.

- Selecting learning methods and techniques.

- Establishing self-pacing within external constraints.

- The conditions for monitoring progression.

- Adopting an active approach vis-à-vis their responsibilities over the learning process.

- The predisposition to take risks.

- The conditions for self-evaluation as regards their learning expectations.

The development of autonomous skills and attitudes should be intentionally addressed in formal education design and improved by individuals in their self-directed learning to take full advantage of social web and web 2.0 affordances. Building a dynamic ecology for self-development may then be possible thanks to the rich and diverse set of learning opportunities available in the digital era.

\subsection{Personal pedagogies}

Is it contradictory to talk about a personal pedagogy when pedagogy is traditionally defined as a method or practice of teaching? Pedagogy involves a certain degree of awareness not particularly of what is to be learnt, but an emphasis on how to facilitate learning. While attempting to question this clear-cut division of presupposed roles and responsibilities between teachers and learners we could mention the different levels of student involvement in pedagogical decisions that already exist within formal education. We have found examples of formal learning where spaces for pedagogy discussion are possible: negotiated curriculum (Williams, Karousou, \& Mackness, 2011), learners-and-teacher course co-design (Garcia, 2014), open content courses (Bruce \& Zheng, 2010), personalized learning (Redding, 2013), and learner generated content (Pérez-Mateo, Maina, Guitert, \& Romero, 2011). 
In this section, and in line with the idea of personal pedagogies, we explore trends in web enabling services and technologies supporting learning ecologies that permeate formal, non-formal and informal learning, paying special attention to emerging or renewed pedagogies that allow autonomy and self-direction in personal learning trajectories. Discussion and specific policies recognizing non-formal and informal learning (CEDEFOP, 2009; European Commission, Cedefop \& ICF International, 2014; Werquin, 2010) are positive incentives that encourage people to become actively involved in seamless lifelong learning.

This list is not exhaustive and in some cases items may overlap and intersect in the way in which they are approached. The trends comprising technologies, pedagogies and strategies illustrate a whole landscape of choices of autonomous learning in the digital era. Technology affordances have multiplied and simplified opportunities for learning. We are fully aware that creativity will provide new ways of combining them and generating new ones.

\section{$5.3 \quad$ MOOC}

MOOC stands for Massive Open Online Course. These are courses offered to large numbers of students worldwide and usually for free. Since the first experience in 2008 with the "Connectivism and Connective Knowledge" MOOC (Bell, 2010), this phenomenon has grown exponentially in number (Shah, 2014) and new MOOC formulas are being tried out. However, the primary pedagogical approach rests on what Rodriguez (2012) calls AIStanford-like courses. AI-Stanford was another highly successful pioneering MOOC on Artificial Intelligence offered in 2011 by Stanford University. This denomination is also known as XMOOC, which emerged to differentiate it from the connectivists' cMOOC. Even if this binary classification is a simplification, it is useful for explaining a whole spectrum of MOOCs in between these two poles.

The XMOOCs are predominantly courses developed using cognitive and behaviorist principles. The teacher constitutes "the most relevant and reliable source of knowledge and information" (Guàrdia, Maina \& Sangrà, 2013, p.2) and establishes a mediated 'presence' in a series of short lecture videos. Additional learning resources (usually freely available on the web), a set of learning tasks or exercises, and automated assessment, such as quizzes, 
complete the basics of an xMOOC. Participation in discussion forums and some forms of peer support and evaluation are common in many xMOOCs. On the other hand, cMOOCs implement connectivist principles where the nodes and the network are reified. Learners are empowered in multiple ways by contributing to building a network of participants, creating their personal learning environments, choosing, aggregating and sharing learning resources, co-evaluating and providing peer support. The premise is "knowledge creation and generation" (Siemens, 2012).

The MOOC as a phenomenon is rapidly evolving and the learning opportunities it offers may become a significant part of a personal learning ecology. As recent research (Liyanagunawardena, Parslow, \& Williams, 2014; Zheng, Rosson, Shih, \& Carroll, 2015) has shown, the number of participants registered on MOOCs who complete the entire course is low (under 10\%) (Gütl, Rizzardini, Chang, \& Morales, 2014), but there is also evidence that this is not necessarily caused by dropouts due to poor course quality or the participant's lack of motivation. Participants are declaring an interest in 'bits' of information in the MOOC or in specific sections of the course. This is congruent with individuals who have clear learning goals that choose from the available educational resources that best fit their needs. Since MOOCs are organized educational pieces designed and planned by teachers and faculty, identifying and matching the explicit learning objectives of the course and the implicit or less clearly defined personal ones is relatively easier. MOOCs provide the opportunity to benefit from more experienced peers and contribute to social learning. They offer the additional motivation of interacting with people with similar interests. Furthermore, people concerned with gaining recognition for their learning may also benefit from MOOC accreditation where statements of accomplishment and badges are commonly granted. Coursera's (http://www.coursera.org) initiative known as a "signature track" is already offering "specializations" consisting of a series of interrelated courses signifying another step in the open educational offer, this time, for a small fee. Badges and completion certificates from recognized educational institutions and prestigious universities can enrich a personal e-portfolio, whether this is used for learning or other purposes. 

Maina (Eds.), The Future of Ubiquitous Learning: Learning Designs for Emerging Pedagogies (pp. 73-94). Lecture Notes in Educational

Techno

\subsection{Current awareness}

Current awareness techniques support updating, upgrading and even foreseeing any particular topic as it evolves, and allow a person to oversee a subject of interest. The idea of keeping up with relevant and up-to-date information is not necessarily new. University libraries usually offer this service to their faculty by providing recently published literature in a specific field or subject. However, Web 2.0 ('prosumers' web) and Web 3.0 (semantic web) are offering a much broader array of services that provide user self-sufficiency and customizing options as never before. If we explore some of them, we can see how they may be an extraordinary ally of motivation and self-development. The benefits of automatic alerts like the ones we describe below are enormous compared with the required unique action of "subscribing" or a set of actions for configuring a current awareness space within a personal ecology.

Mailing lists together with news groups and newsletters are probably the best known ways to receive new information from specialized websites, companies or groups of people interested in the same issues. Mailing lists are a collection of names and electronic addresses used to distribute information to multiple recipients (e.g. Instructional Systems Technology mailing lists at Indiana University Bloomington: http://education.indiana.edu/about/ departments/instructional/email-lists.html). This collection of addresses can also be used to send electronic bulletins, also known as newsletters (e.g. Eportfolio European project and portal newsletter: http://www.europortfolio.org/ newsletter), which are periodically distributed by an organization or business. Mailings lists and newsletters are a more passive action whereby we receive e-mails about ongoing events related to our concerns. Newsgroups are Internet-based discussion forums where participants with common interests engage in debates (e.g. ITF forum: http://itforum.coe.uga.edu/). As the definition shows, newsgroups are horizontal, allowing each subscriber to voice their own opinion. They usually have a moderator who ensures a respectful and productive exchange and may, in some cases, filter messages in accordance to the newsgroup rules.

However, RSS (Rich Site Summary, also known as Really Simple Syndication) has actually enhanced the way in which we can stay informed. It is a technology that allows users to keep track of regular changes in web content by subscribing to feeds (a data format used to distribute websites' 
recently added content). This web content may also come from selected bloggers the user has chosen to follow because of their expertise or the opinions they share. New content also includes new issues of academic journals, the appearance of specialized magazines, or any other website that has enabled this function. There numerous ways to set up an RSS feed.

Applications like Flipboard (flipboard.com) or Feedly (feedly.com) allow users to aggregate RSS feeds from diverse web sources all in one place. They support visual display, customization and sharing. These RSS readers simplify the way in which we organize and keep track of the information we gather and read. They leverage the new affordances of the social web as they integrate advanced sharing options in any type of social network, like Facebook (www.facebook.com), Google+ (plus.google.com), LinkedIn (www.linkedin.com), etc. They are cloud based and developed using responsive design, allowing them to be viewed from any device.

Bookmarking and other forms of archiving web content are other techniques of current awareness. Bookmarking is way to record and organize any kind of web content for future access. Popular bookmarking applications like Delicious (delicious.com), Diigo (www.diigo.com) and Zotero (www.zotero.org) have evolved by supporting different ways to build personal or group bookmarks, annotate links and share them on multiple platforms. Tagging options allow a more dynamic way of organizing and reorganizing resources according to specific or immediate use needs. Applications like Evernote and Google Keep are cloud-based note-taking services that allow users to collect almost every content available on the Web, organizing, classifying, tagging and sharing or following others. One way to stay in tune with the constant fluidity of knowledge is to be a curator or subscribe to curators of specific subject matters or topics. Publishing platforms like Scoop.it (www.scoopit.com) support easy ways to create boards and participate in a criterion-based strategy for keeping track of the state-of-the-art of a content problem.

All the available applications and services tend to integrate new functionalities and are converging into fully functional, flexible and customizable ways to support current awareness. 

Maina (Eds.), The Future of Ubiquitous Learning: Learning Designs for Emerging Pedagogies (pp. 73-94). Lecture Notes in Educational

Techno

\subsection{E-Portfolios}

E-portfolios or electronic portfolios are digital versions of the traditional portfolios found in educational or professional contexts. There are several definitions of e-portfolios, most of them highlighting one aspect, usually the context of use or the purpose of this broad digital solution. The e-Portfolio European Network (www.eportfolio.org) has adopted an inclusive definition as follows: "ePortfolio is an umbrella term for a structured collection of self or co-created digital artifacts, recognitions, and accreditations where the owner has enough freedom to arrange their presentation according to specific purposes and audiences." Digital or electronic portfolios also represent a significant improvement thanks to Internet affordances and increased connectivity. The emphasis in the history of portfolios, in the phase of digital networks, has shifted from collecting to also communicating and exchanging.

There are numerous applications for building an e-portfolio. In most educational institutions existing Learning Management Systems or dedicated software (e.g. Mahara - mahara.org, PebblePad - www.pebblepad.co.uk) are used to support e-portfolios for teaching and learning at the course and the program level (Downs, Jenkins \& Repman, 2013). Programs designed according to competency-based learning usually deploy a competency profile where a set of clustered competencies help articulate the courses and provide program consistency (Wassef, Riza, Maciag, Worden, \& Delaney, 2012). Competencies serve as logical organizers for collecting evidence in intelligible and communicable ways. They also support transition eportfolios connecting student life to work life. Ownership is a key issue for institution e-portfolios. The more transferable they are the better for the student's lifelong learning and career development. They should provide eportfolio portability.

From an individual perspective, developing a personal e-portfolio may become an integral part of a self-development strategy. Whether started within a formal learning situation while taking part in a program or initiated on one's own, e-portfolios are flexible enough to support a variety of purposes (JISC, 2012). They support learning and reflection and are a valuable option for formative assessment. They may also be used for showcasing one's achievements for professional projection or job seeking. They may contribute to the creation and management of a digital identity. In summary, e-portfolios support a "Personal Development Planning" (PDP) 
through learning ecologies. In B. Gros, Kinshuk, \& M. Maina (Eds.),

The Future of Ubiquitous Learning: Learning Designs for Emerging

Pedagogies (pp. 73-94). Lecture Notes in Educational Techno.

Articulating personal pedagogies through learning ecologies

understood as "a structured and supported process undertaken by an individual to reflect upon their own learning and achievement and to plan for their personal educational and career development" (Strivens, 2007, p.3). Studies in PDP and e-portfolios for career success are showing promising results (Faulkner, Mahfuzul Aziz, Waye \& Smith, 2013).

Web 2.0 and social web technologies and practices have substantially increased the ability to integrate applications and services for e-portfolio implementation as well as the opportunities for opening it up to interaction, discussion and feedback. Wikis, blogs and cloud computing services together with social networks like Facebook and LinkedIn can be seamlessly connected to build a multimedia-rich environment with social affordances. All kinds of digital assets - digital certification from recognized institutions, badges from MOOCs, videos or digital presentations or productions from learning or work, documents of all kinds, etc.- can be easily stored, organized and published through an e-portfolio on the web (McKenna, \& Stansfield, 2013).

\subsection{Social networks and communities}

For authors like Siemens (2005) and Downes (2012) traditional learning theories of behaviorism, cognitivism and constructivism do not provide fully explanatory power for learning in the digital era. They propose the "connectivist" learning theory which emphasizes that learning is the capacity to establish meaningful connections to nodes, whether human or not. This approach situates networks at the core of social and personal knowledge creation.

Dron and Anderson (2014) advance a typology of social forms for learning, namely "groups", "nets" and "sets". These different configurations allow any individuals to "benefit from one another's knowledge and actions" (p. 73). While "groups" are usually formed within formal education (classes, tutorial groups, seminar groups, workshops, cohorts, etc.), "net" learning consists of nodes (e.g. people, objects, ideas) and edges (the connections between them) that usually emerge and consolidate at the initiative of the participants themselves. They tend to be stable and support fluid horizontal communication and exchange between members regarding changing or evolving common subjects or concerns. Finally, in "sets" people establish 
Chapter Maina, M. \& Garcia, I. (2016). Articulating personal pedagogies through learning ecologies. In B. Gros, Kinshuk, \& M. Maina (Eds.), The Future of Ubiquitous Learning: Learning Designs for Emerging Pedagogies (pp. 73-94). Lecture Notes in Educational

Techno

less perennial ties with regards to particular interests. Sets are more defined by "picking up" things than on the social exchange with others.

The interest in participating and socializing has precipitated the rise of differentiated network systems. From a technological perspective, network systems are services that provide any individual with ways to connect and establish social relationships for groups, nets or sets configurations. Although any taxonomy is somewhat reductionist, the best known social networks have recognizable orientations and attract people for different purposes: Facebook (www.facebook.com) gathers all kinds of individuals sharing personal life events and general interests where participants are recognized as "friends"; LinkedIn (www.linkedin.com) assembles people seeking to establish professional liaisons or connects prospects with potential employers; Academia.edu (www.academina.edu) or ResearchGate (www.researchgate.net) are research-oriented spaces connecting faculty and researchers; Twitter (twitter.com), the microblogging application par excellence, either for personal or professional ends, is characterized by disseminating instantaneous short messages and providing streaming communication capabilities. On-top services like TweetDeck (tweetdeck.twitter.com) for Twitter provide additional functionalities for improved visualization of streamed information through custom timelines or track of lists, searches and activities.

But there are also many networks that form around media (video, pictures, images, texts, etc.) sharing services like YouTube (www.youtube.com), Flickr (www.flickr.com), Pinterest (www.pinterest.com), Instagram (instagram.com), Issu (issu.com), to name just a few. As the Pee Wee report (Duggan, Ellison, Cliff Lampe, Lenhart, \& Madden, 2015) shows, there is a growing number of users participating in more than one social network.

Networks are plastic and may support learning in more or less engaging ways. Communities of practice (CoP), a type of group-net intersection, are identified by an active and persistent involvement of "practitioners" with similar goals that exchange and produce meaningful knowledge resources within a shared repertoire and improve practice (Wenger, 1998). Participants' experience and expertise are crucial and define membership and role status within the community and build a collective identity. They are domain-oriented and they share common concerns for meaning-making and personal development. According to Bates (2015, p. 129), "A large part of the lifelong learning market will become occupied by communities of 
through learning ecologies. In B. Gros, Kinshuk, \& M. Maina (Eds.),

The Future of Ubiquitous Learning: Learning Designs for Emerging

Pedagogies (pp. 73-94). Lecture Notes in Educational Techno.

Articulating personal pedagogies through learning ecologies

practice and self-learning, through collaborative learning, sharing of knowledge and experience, and crowd-sourcing new ideas and development." CoP are common in medical, education and software engineering disciplines and within companies.

While CoP are a more homogenous domain-oriented type of grouping, Communities of Interest $(\mathrm{CoI})$ constitute a heterogeneous group of people with different backgrounds and experiences (Fischer, 2001). They are, in terms of Dron and Anderson (2014), a type of group-set intersection. In CoI "members take part in the community to exchange information, to obtain answers to personal questions or problems, to improve their understanding of a subject, to share common passions or to play" (Henri, \& Pudelko, 2003, p. 478). Learning is more a personal effect of a shared enterprise that does not require the development of an artifact as in CoP. The involvement is more dissimilar since individual needs are the primary motivation for participation.

Even if networks for learning have existed for a period of time, new social networks are shaping the way in which people communicate, exchange information and even socialize. Networks intersect personal and professional life, including learning. Both individuals and educational institutions and organizations are being challenged to make the most of them.

\section{CONCLUSIONS: ECOLOGICAL SETTING FOR LEARNING}

The technological landscape of applications and services has matured to a point where adoption, appropriation and use are no longer a barrier. Opportunities for collecting, creating and sharing content and knowledge are multiple. Furthermore, efforts are being made to facilitate methods for recognizing non-formal and informal learning (Cedefop 2009, Souto-Otero, Murphy, Duchemin, et al., 2014). Formal learning offered by Higher Education institutions and non-formal education from a variety of providers in the private and public sectors are being rethought in order to leverage emerging technologies and in accordance with the principles of open accessible education. The response is enabling all kinds of learning scenarios and personalization opportunities for learning. We could conclude that the 
Chapter Maina, M. \& Garcia, I. (2016). Articulating personal pedagogies through learning ecologies. In B. Gros, Kinshuk, \& M. Maina (Eds.), The Future of Ubiquitous Learning: Learning Designs for Emerging Pedagogies (pp. 73-94). Lecture Notes in Educational

Techno

setting is sufficiently grounded to support lifelong learning and personal and professional development.

The self is the key and the challenge to face in the coming years. Autonomous learning supposes some forms of self-regulation. Self-regulated learning is demanding since it assumes that people are "metacognitively, motivationally and behaviorally active" (Zimmerman, 1989, p. 329) in their own learning process. But there is also a crucial role played by others (teachers, peers, experts, etc.) in the successful development of selfregulation (Zimmerman, 2000). The distinctive characteristics of autonomy in learning are congruent with the 21 st century competencies framework, particularly those related to "self-direction, adaptability, flexibility, and collaboration" (Wolters, 2010, p. 18). Substantive theory, enabling technologies, educational change, and self-dispositions are making it possible to draw up a comprehensive framework in which individuals may build personal trajectories of learning and development in flexible and organic ways, where they can enact personal pedagogies.

\section{REFERENCES}

Andrade, M. S., \& Bunker, E. L. (2009). A model for self-regulated distance language learning. Distance Education, 30(1), 47-61.

Attwell, G. (2007). Personal Learning Environments. The future of e-learning? eLearning Papers, 2(1).

Barab, S. A., \& Roth, W. M. (2006). Curriculum-based ecosystems: Supporting knowing from an ecological perspective. Educational Researcher, 35(5), 3-13.

Barron, B. (2004). Learning ecologies for technological fluency in a technology-rich community. Journal of Educational Computing Research, 31, 1-37.

Barron, B. (2006). Interest and self-sustained learning as catalysts of development: A learning ecology perspective. Human Development, 49(4), 193-224.

Bates, T. (2015). Teaching in a Digital Age: Guidelines for designing teaching and learning for a digital age. BC, Canada: Contact North. Retrieved from http://opentextbc.ca/teachinginadigitalage/

Bell, F. (2010). Connectivism: Its place in theory-informed research and innovation in technology-enabled learning. The International Review of Research in Open and Distance Learning, 12(3), 98-118.

Biesta, G. \& Tedder, M. (2007). Agency and learning in the lifecourse: Towards an ecological perspective. Studies in the Education of Adults, 39(2), 132-149.

Briard, S. \& Carter, C. (2013, November). Communities of practice and communities of interest: definitions and evaluation considerations. Ontario, Canada: Centre of Excellence for Child and Youth Mental Health. Retrieved from: 
through learning ecologies. In B. Gros, Kinshuk, \& M. Maina (Eds.),

The Future of Ubiquitous Learning: Learning Designs for Emerging

Pedagogies (pp. 73-94). Lecture Notes in Educational Techno.

Articulating personal pedagogies through learning ecologies

http://www.niagaraknowledgeexchange.com/wp-

content/uploads/sites/2/2014/05/Communities_of_Practice_Interest.pdf

Bonzo, J. (2012). A Social Media Networked Learning Ecology Perspective. In Hodgson

V, Jones C, de Laat Met al. (Eds) Proceedings of 8th International Conference on Networked

Learning. Maastricht School of Management (pp. 474-481) Maastricht, The Netherlands.

Retrieved from: http://www.networkedlearningconference.org.uk/abstracts/pdf/bonzo.pdf

Brown, J. S. (2000). Growing up Digital: How the web changes work, education, and the

ways people learn. Change: The Magazine of Higher Learning, 32(2), 11-20. Retrieved from: http://www.johnseelybrown.com/Growing_up_digital.pdf

Bruce, P. A., \& Zheng, R. Z. (2011). An Inquiry into the Policies and Practices for Online Education at One U.S. Doctoral/Research-Extensive University: A Case Study. In S.

Huffman, S. Albritton, B. Wilmes, \& W. Rickman (Eds.), Cases on Building Quality Distance Delivery Programs: Strategies and Experiences (pp. 27-43). Hershey, PA: Information

Science Reference. doi:10.4018/978-1-60960-111-9.ch003

CEDEFOP (2009). European guidelines for validating non-formal and informal learning. Luxembourg: Office for Official Publications of the European Communities.

Cormier, D. (2008). Rhizomatic Education: Community as Curriculum. Innovate: Journal of Online Education, 4(5).

Downes, S. (2007). Learning networks in practice. Emerging Technologies for Learning, 2, 19-27. Retrieved from: http://www.downes.ca/files/Learning_Networks_In_Practice.pdf

Downes, S. (2012). Connectivism and Connective Knowledge: Essays on meaning and learning networks. Moncton, New Brunswick: National Research Council of Canada.

Retrieved from: http://www.downes.ca/post/58207

Downs, E., Jenkins, S., \& Repman, J. (2013). Evidence-Based Learning: Threading EPortfolio Development Throughout an Online Graduate Program. In T. Bastiaens \& G. Marks (eds.), Proceedings of World Conference on E-Learning in Corporate, Government,

Healthcare, and Higher Education 2013 (pp. 323-325). Chesapeake, VA: AACE. Retrieved from http://www.editlib.org/p/114855

Dron, T. \& Anderson, T. (2014). A Typology of Social Forms for Learning. In J. Dron \& T. Anderson, Teaching Crowds (pp. 71-91). Edmonton, AB: AU Press.

Duggan, M., Ellison, B., Cliff Lampe, A., Lenhart, A., \& Madden, M. (2015). Social Media Update 2014. Washington DC: Pew Research Center. Retrieved from:

http://www.pewinternet.org/2015/01/09/social-media-update-2014/

Engestrom, Y. (2000). Activity theory as a framework for analyzing and redesigning work. Ergonomics, 43(7), 960-974.

Esposito, A., Sangrà, A., \& Maina, M. (2015). Emerging learning ecologies as a new challenge and essence for e-learning. The case of doctoral e-researchers. In M. Ally \& B. Khan (Eds). Handbook of E-learning (vol.1) (pp. 331-342). NY: Routledge.

European Commission; Cedefop; ICF International (2014). European inventory on validation of non-formal and informal learning 2014. Final synthesis report. Retrieved from: http://libserver.cedefop.europa.eu/vetelib/2014/87244.pdf

Faulkner, M., Mahfuzul Aziz, S., Waye, V., \& Smith, E. (2013). Exploring ways that ePortfolios can support the progressive development of graduate qualities and professional competencies. Higher Education Research \& Development, 32(6), 871-887. doi:

10.1080/07294360.2013.806437 
Chapter Maina, M. \& Garcia, I. (2016). Articulating personal pedagogies through learning ecologies. In B. Gros, Kinshuk, \& M. Maina (Eds.), The Future of Ubiquitous Learning: Learning Designs for Emerging Pedagogies (pp. 73-94). Lecture Notes in Educational

Techno

Fischer, G. (2001). Communities of interest: Learning through the interaction of multiple knowledge systems. In S. Bjornestad, R. Moe, A. Morch, A. Opdahl (Eds) Proceedings of the 24th IRIS Conference (pp. 1-14). August 2001, Ulvik, Bergen, Norway: Department of Information Science. Retrieved from: http://13d.cs.colorado.edu/ gerhard/papers/iris24.pdf

Fischer, G. (2011). Understanding, fostering, and supporting cultures of participation. Interactions, 18(3), 42-53.

Frielick, S. (2004). Beyond constructivism: An ecological approach to e-learning. In R. Atkinson, C. McBeath, D. Jonas-Dwyer \& R. Phillips (Eds), Beyond the comfort zone: Proceedings of the 21st ASCILITE Conference (pp. 328-332). Perth. Western Australia. Retrieved from http://www.ascilite.org.au/conferences/perth04/procs/frielick.html

Garcia, I. (2014). Analyzing University Students' Participation in the Co-Design of Learning Scenarios. In Polman, J. L., Kyza, E. A., O'Neill, D. K., Tabak, I., Penuel, W. R., Jurow, A. S., O'Connor, K., Lee, T., and D'Amico, L. (Eds.). (2014). Learning and becoming in practice: The International Conference of the Learning Sciences (ICLS) 2014, Vol. 3. (pp. 1072-1076). Boulder, CO: International Society of the Learning Sciences. Retrieved from: https://isls.org/icls/2014/downloads/ICLS\%202014\%20Volume\%203\%20\%28PDF\%29wCover.pdf

Goodyear, P. (1998) New technology in higher education : understanding the innovation process. In Eurelings, A. et al (Eds.), Integrating information and communication technology in higher education (pp. 107-136). Kluwer: Deventer.

Guàrdia, L., Maina, M. \& Sangrà, A. (2013). MOOC Design Principles. A Pedagogical Approach from the Learner's Perspective. eLearning Papers, 33.

Gütl, C., Rizzardini, R. H., Chang, V., \& Morales, M. (2014). Attrition in MOOC: Lessons Learned from Drop-Out Students. In Learning Technology for Education in Cloud. MOOC and Big Data. Communications in Computer and Information Science, 446 (pp. 37-48). Springer International Publishing.

Haythornthwaite, C. \& Andrews, R. (2011). E-learning theory and practice. London: Sage Publications.

Heimlich, J. E., \& Horr, E. E. T. (2010). Adult learning in free-choice, environmental settings: What makes it different? New Directions for Adult and Continuing Education, 127, 57-66. doi:10.1002/ace

Henri, F., \& Pudelko, B. (2003). Understanding and analysing activity and learning in virtual communities. Journal of Computer Assisted Learning , 19(4), 474-487. doi: 10.1046/j.0266-4909.2003.00051.x

Holec, H. 1979/1981. Autonomie et apprentissage des langues étrangères. Strasbourg: Council of Europe. (English translation published in 1981 as Autonomy in Foreign Language Learning. Oxford: Pergamon). Retrieved from:

http://unpan1.un.org/intradoc/groups/public/documents/apcity/unpan007791.pdf

Jackson, N. J. (2013). The Concept of Learning Ecologies. In in N, Jackson \& G. B. Cooper (Eds) Lifewide Learning, Education and Personal Development E-Book (pp. 1-21). . Retrieved from: http://www.lifewideebook.co.uk/uploads/1/0/8/4/10842717/chapter_a5.pdf

JISC (2012). E-portfolio implementations toolkit. Retrieved from: https://epip.pbworks.com/w/page/28670505/The\%20e-

portfolio\%20implementation\%20toolkit 
through learning ecologies. In B. Gros, Kinshuk, \& M. Maina (Eds.), The Future of Ubiquitous Learning: Learning Designs for Emerging Pedagogies (pp. 73-94). Lecture Notes in Educational Techno. Articulating personal pedagogies through learning ecologies

Kanuka, H. (2008).Understanding e-Learning Technologies-in-Practice through Philosophies-in-Practice. In T. Anderson (Ed.), The theory and practice of online learning (2nd ed.) (pp. 91-118). Athabasca University Press.

Kemmis, S., Wilkinson, J., Hardy, I., \& Edwards-Groves, C. (2009, November). Leading and learning: Developing ecologies of educational practice. In Annual Meeting of the Australian Association for Research in Education, Canberra, Australia..

Law, J. (1992). Notes on the theory of the actor-network: Ordering, strategy, and heterogeneity. Systems practice, 5(4), 379-393.

Lemke, J. L. (2000). Across the scales of time: Artifacts, activities, and meanings in ecosocial systems. Mind, culture, and activity, 7(4), 273-290.

Liyanagunawardena, T. R., Parslow, P. and Williams, S. (2014) Dropout: MOOC participants'perspective. In U. Cress \& C. Delgado Kloss (eds.), EMOOCs 2014, the Second MOOC European Stakeholders Summit (pp. 95-100). Barcelona, Spain: p.a.u. Education.

Looi, C. K. (2001). Enhancing learning ecology on the Internet. Journal of Computer Assisted Learning, 17(1), 13-20.

Luckin, R. (2008). The learner centric ecology of resources: A framework for using technology to scaffold learning. Computers \& Education, 50(2), 449-462.

Luckin, R. (2010). Re-designing learning contexts. Technology-rich, learner-centred ecologies. London and New York: Routledge.

Luckin, R., Clark, W., Garnett, F., Whitworth, A., Akass, J., Cook, J., Day, P., Ecclesfield, N., Hamilton, T., \& Robertson, J. (2010). Learner-Generated Contexts: A Framework to Support the Effective Use of Technology for Learning. In M. Lee, \& C. McLoughlin (Eds.), Web 2.0-Based E-Learning: Applying Social Informatics for Tertiary Teaching (pp. 70-84).

Hershey, PA: Information Science Reference. doi:10.4018/978-1-60566-294-7.ch004

McKenna, G. F., \& Stansfield, M. H. (2013). Identification of key issues in adopting a Web 2.0 E-portfolio strategy. International Journal of Virtual and Personal Learning Environments (IJVPLE), 4(1), 49-64. doi:10.4018/jvple.2013010104

Moore, M.G. (1972). Learner autonomy: The second dimension of independent learning. Convergence, 5(2), 76-88. Retrieved from:

http://www.ajde.com/Documents/learner_autonomy.pdf

Moore, M.G. (2007). The theory of transactional distance. In M.G. Moore (ed.), Handbook of distance education (2nd ed.) (pp. 89-105). Mahwah, NJ: Lawrence Erlbaum.

Nardi, B., \& O'Day, V. (1999). Information Ecologies: Using Technology with Heart: Chapter Two: Framing Conversations about Technology. First Monday, 4(5).

Nixon, S. (2013). Personal development planning; an evaluation of student perceptions. Practice and Evidence of the Scholarship of Teaching and Learning in Higher Education, 8(3), 203-216.

Pérez-Mateo, M., Maina, M. F., Guitert, M., \& Romero, M. (2011). Learner generated content: Quality criteria in online collaborative learning. European Journal of Open, Distance and E-Learning - EURODL. Special Themed Issue on Creativity and Open Educational Resources (OER). Retrieved from: http://www.eurodl.org/materials/special/2011/PerezMateo_et_al.pdf

Redding, S. (2013). Getting personal: The promise of personalized learning. In M. Murphy, S. Redding, \& J. Twyman (eds.), Handbook on innovations in learning (pp.113130). USA, PA: Center on Innovations in Learning. 
Richardson, A. (2002) An ecology of learning and the role of elearning in the learning environment. Global Summit Education AU Limited Global Summit. Retrieved from http://unpan1.un.org/intradoc/groups/public/documents/apcity/unpan007791.pdf

Rongbutsri, N., Ryberg, T., \& Zander, P-O. (2012). Personalized learning Ecologies in Problem and Project Based Learning Environments. In R. Ørngreen (Ed.) Designs for learning 2012, Proceedings of the 3rd International Conference Exploring Learning Environments (pp. 164- 165). København, Copenhagen, Denmark.

Saadatmand, M., \& Kumpulainen, K. (2012). Emerging Technologies and New Learning Ecologies: Learners' Perceptions of Learning in Open and Networked Environments. In Proceedings of the 8th Int. Conf. on Networked Learning (pp. 266-275).

Scharle, Á., \& Szabó, A. (2000). Learner autonomy: A guide to developing learner responsibility. UK: Cambridge University Press.

Shah, D. (2014, December 26). MOOCs in 2014: breaking down the numbers. EdSurge Newsletter. Retrieved from: https://www.edsurge.com/n/2014-12-26-moocs-in-2014breaking-down-the-numbers

Siemens, G. (2003, October 17). Learning ecology, communities, and networks: Extending the classroom [Blog post]. elearnspace. Retrieved from http://www.elearnspace.org/Articles/learning_communities.htm Siemens, G. (2005). Connectivism: A learning theory for the digital age. International Journal of Instructional Technology and Distance Learning, 2 (1). Retrieved from: http://www.itdl.org/Journal/Jan_05/article01.htm

Siemens, G. (2007). Connectivism: Creating a learning ecology in distributed environments. In T. Hug, (Ed.) Didactics of microlearning: Concepts, discourses, and examples. (pp.53-68). Munster, Germany: Waxmann Verlag.

Siemens, G. (2008). New Structures and spaces of learning: The systemic impact of connective knowledge, connectivism and networked learning. Encontro sobre Web 2.0 Universidade do Minho. Braga, Portugal. Retrieved from http://elearnspace.org/Articles/systemic_impact.htm

Siemens, G. (2012, July 25). MOOCs are really a platform. eLearnspace. Retrieved from: http://www.elearnspace.org/blog/2012/07/25/moocs-are-really-a-platform/

Smith, R. (2003). Pedagogy for autonomy as (becoming-)appropriate methodology. In D. Palfreyman \& R. C. Smith (eds), Learner Autonomy across Cultures: Language Education Perspectives (pp.129-146). Basingstoke: Palgrave Macmillan.

Souto-Otero, M., Murphy, I., Duchemin, C., Howley, J., Alvarez Bermúdez, N. \& Coles, M. (2014). European Inventory on validation of non-formal and informal learning 2014. Final synthesis report. European Commission. Retrieved from http://opus.bath.ac.uk/42564/1/European_inventory_final_synthesis_report.pdf

Strivens, J. (2007). A survey of e-pdp and e-portfolio practice in UK Higher Education. Heslington, York, UK: The Higher Education Academy. Retrieved from http://aces.shu.ac.uk/support/staff/employability/resources/survey_of_epdp_and_eportfolio_p ractice_in_uk_higher_education.pdf

Tabuenca, B., Ternier, S., \& Specht, M. (2013). Supporting lifelong learners to build personal learning ecologies in daily physical spaces. International Journal of Mobile Learning and Organisation, 7(3), 177-196. 
Maina, M. \& Garcia, I. (2016). Articulating personal pedagogies

through learning ecologies. In B. Gros, Kinshuk, \& M. Maina (Eds.),

The Future of Ubiquitous Learning: Learning Designs for Emerging

Pedagogies (pp. 73-94). Lecture Notes in Educational Techno.

Articulating personal pedagogies through learning ecologies

Thomas, H. (2010). Learning spaces, learning environments and the dis 'placement' of learning. British Journal of Educational Technology, 41(3), 502-511.

Wassef, M. E., Riza, L., Maciag, T., Worden, C., \& Delaney, A. (2012). Implementing a

competency-based electronic portfolio in a graduate nursing program. Computers Informatics Nursing, 30(5), 242-248.

Weller, Martin (2011). A pedagogy of abundance. Spanish Journal of Pedagogy, 249, 223-236.

Wenden, A. 1998. Learner Strategies for Learner Autonomy. Great Britain: Prentice Hall.

Wenger, E. (1998). Communities of practice: learning, meaning, and identity. New York: Cambridge University Press.

Wenger, E., McDermott, R. A., \& Snyder, W. (2002). Cultivating communities of practice: A guide to managing knowledge. Harvard Business Press.

Werquin, P. (2010). Recognising non-formal and informal learning: Outcomes, policies and practices. OECD. Retrieved from http://www.oecd.org/education/skills-beyondschool/44600408.pdf

Williams, R., Karousou, R., \& Mackness, J. (2011). Emergent learning and learning ecologies in Web 2.0. The International Review of Research in Open and Distributed Learning, 12(3), 39-59.

Wolters, C. (2010). Self-regulated learning and the 21st century competencies. Paper prepared for the NRC Planning Meeting on 21st Century Competencies. Retrieved from http://www.hewlett.org/uploads/Self_Regulated_Learning_21st_Century_Competencies.pdf

Zheng, S., Rosson, M. B., Shih, P. C., \& Carroll, J. M. (2015). Understanding Student Motivation, Behaviors, and Perceptions in MOOCs. In Proceedings of the 18th ACM Conference on Computer Supported Cooperative Work \& Social Computing (pp. 1882-1895). New York, NY, USA: ACM. doi: 10.1145/2675133.2675217

Zimmerman, B. J. (1989). A social cognitive view of self-regulated academic learning. Journal of educational psychology, 81(3), 329-339. doi: 10.1037/0022-0663.81.3.329

Zimmerman, B. J. (2000). Attaining Self-Regulation: A Social Cognitive Perspective. In M. Boekaerts, P. R. Pintrich, \& M. Zeidner (eds.), Handbook of Self-Regulation (pp. 13-39). Burlington, MA, USA: Elsevier Academic Press. doi:10.1016/B978-012109890-2/50031-7 